\begin{tabular}{|c|c|}
\hline \multirow{3}{*}{ 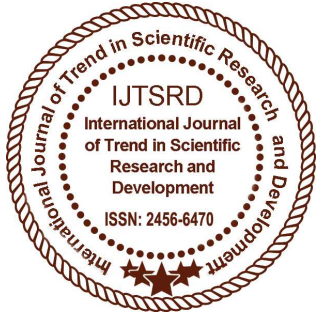 } & $\begin{array}{l}\text { International Journal of Trend in Scientific } \\
\text { Research and Development (IJTSRD) }\end{array}$ \\
\hline & International Open Access Journal \\
\hline & ISSN No: 2456 - 6470 | www.ijtsrd.com | Volume - 2 | Issue - 4 \\
\hline
\end{tabular}

\title{
A Study on Linkage between Corporate Social Responsibility and Return on Net Worth (RONW) of 5 Public Companies
}

Dr. Ritu Wadhwa

Assistant Professor, Department of Finance, Amity Business School, Amity University, Noida

\author{
Ms Kunika Bhargava \\ Student, Amity Business School, \\ Amity University, Noida, India
}

\begin{abstract}
The purpose of the present paper is to study the linkage of CSR initiatives taken by the Indian companies and its impact on their RONW. For this purpose, various financial parameters have been used like Return on net worth, profit before tax and earnings per share. Researchers have taken a sample of 5 public companies namely Tata Steel Company, RIL, Mahindra \& Mahindra, ITC and Larsen and Toubro to examine the relationship between corporate social responsibility and RONW by considering their financial statement of five years (from March 2013 to March 2017). The logic behind to take such samples is that these are big public key players with respect to Indian business.
\end{abstract}

After getting all the data, an analysis on the relationship between CSR and other financial parameters like EPS, PBT and RONW are tested by Regression analysis and ANOVA.

Irrespective of this general outcome, the current study depicts evidence that there is a insignificant relationship between CSR and Return on Net Worth (RONW) in case of these companies.

Keywords: Corporate Social Responsibility, EPS, $P B T, R O N W$, Financial performance

\section{INTRODUCTION}

CSR is not a new concept in India. Business concepts have shifted from profitable returns to social improvement activities, where the business is responsible for all stakeholders, not just shareholders.
Traditionally, corporate social responsibility has more definitions in the charity model. Over time, the concept of corporate social responsibility has undergone tremendous changes. This paper focuses on the CSR activities of these Indian listed companies, and how they relate to profitability and their desire to participate in these CSR activities. In the modern era of the business world, corporate social responsibility is the company's constant commitment to ethical behavior and contributes to economic development while improving the quality of life of the workforce and its families, as well as local communities and society as a whole.

With the increasing global awareness of environmental, social and ethical issues, corporate social responsibility is now considered an integral part of the corporate sector in each country. In order to understand the benefits of corporate social responsibility in corporate social responsibility, a lot of research has been conducted. Although many countries, including India, believe that corporate social responsibility is a means of window decoration, and it is not conducive to the development and profitability of enterprises. In addition, many companies believe that corporate social responsibility improves image and contributes to the long-term sustainability of the business. Corporate Social Responsibility (CSR) is a concept that suggests that it is the responsibility of the corporations operating within society to contribute towards economic, social and environmental development that creates positive impact on society at large. It refers to the 
company is responsible for its impact on society. The European Commission believes that CSR is very important for the sustainability, competitiveness and innovation of EU companies and the EU economy. It brings benefits for risk management, cost savings, capital acquisition, customer relations and human resource management.

In today's highly competitive world, corporate social responsibility has become the soul of every company, and it has competitive advantages and ensures sustainable growth. The impact of corporate activities on the environment and society increases the importance of sustainable practices and corporate social responsibility. The increasing pressure on agents has prompted companies to implement corporate social responsibility activities to disclose their behavior and achievements.

The government's action has become a mandatory measure that is mandatory for public disclosure because the government can force private entities to disclose information, and the legislation transparently expresses and formulates disclosure requirements based on the legitimacy of democratic procedures.

Profitability is a measure of financial gains as measured by price-to-income ratios. It is considered as a test of efficiency because high-profit companies or companies are more efficient than low-profit companies. Profit is the yardstick for economic efficiency, management efficiency, and social goals. As Weston and Brigham rightly pointed out: "The profit on financial management is a test of efficiency and control measures, a measure of the value of their investment for the owner, giving the creditor a safe margin to the government. On the basis of taxable scale capabilities and legislative actions, state profits are indicators of economic progress, national income and living standards, and profits are the result of profits. In other words, there is no profit-driven profit. Every company hopes to be better today than today and tomorrow will be better. This is why they are profitable.

\section{Why is CSR important?}

For the benefit of the company - Corporate Social Responsibility provides the company with important benefits in risk management, cost savings, capital acquisition, customer relations, and human resource management and innovation capabilities.
For the benefit of the EU economy - Corporate social responsibility makes the company more sustainable and innovative, which helps to achieve a more sustainable economy.

For the benefit of society - Corporate Social Responsibility provides a series of values through which we can build a more cohesive society and transform it into a sustainable economic system.

\section{Overview of CSR activities of TSC, RIL, L\&T, M\&M and ITC}

Tata Steel has been committed to the advancement and development of society in Jharkhand State for the past 100 years. It has always been committed to improving the quality of life in its communities. Social development and community welfare in the Jharkhand community have been internalized since its establishment and have been used up to now, making Tata Steel a leader in the region. Social commitment... In the half-century of industrial innovation, the wealth created by Justegita Tata and his sons formed a small part of their rich country. All these wealth's are trusted by the people and are dedicated to their interests. The cycle is thus completed: People happen to return to the people many times. For Jamsetji Tata, the progress of the enterprise, the welfare of the people and the health of the enterprise are inseparable. The Indian Times stated in 1912 that Tata's said that the generation of wealth and wealth had never "disappeared on its own, but rather a means to end India's growing prosperity." Successive generations of Tata Group leaders have always believed that the success of material conditions is not worthwhile unless it is in the national interest and is achieved through fair and honest methods.

Reliance India Limited has contributed to the community in many ways which includes health, education, infrastructure (drinking water, improving village infrastructure, construction of schools, etc.), environment (sewage treatment, tree planting, hazardous waste disposal), aid and assistance to other social development organizations Other activities, etc. RIL's CSR team in its manufacturing department regularly interacts with neighboring communities. RIL plays a key role in supporting the government's promotion of girls' education. In Gujarat, under the "Kanya Kelvani" project, Rhe's Dahej manufacturing department has expanded financial aid for girls' education in the state. RIL developed a community medical center near most of its manufacturing 
departments to provide comprehensive health services. Prevent, promote and provide curative health services to communities from neighboring villages.

Larsen and Toubro: L\&T believes that true and full growth, success and operational measures are not limited to the balance sheet or any economic indicators. This is best reflected in the difference between business and industry in people's lives. Through its social investment, it solves the needs of communities living near its facilities and takes sustainable initiatives in the areas of health, education, environmental protection, and infrastructure and community development.

M\&M defines CSR as creating products that are socially responsible, participating in socially responsible employee relations, and committing to the communities around them. At the

Mahindra Group, corporate social responsibility is more than just an obligation; it is a way of life. In 2005, the Group celebrated its sixtieth anniversary by renewing its commitment to corporate social responsibility. It promises to continue to invest mandatory amounts to achieve social benefits. Launched a unique ESOPs to enable Mahindra employees to participate in their chosen social responsibility activities. The organization also announced a special gift for 60 hearing impaired, unidentified children to provide free cochlear implantation.

ITC - inspired by the overall vision of contributing to the achievement of national goals for sustainable development and inclusive growth, ITC has innovatively developed a unique business model that combines long-term shareholder value creation with enhanced social capital.

ITC not only measured achievements in terms of financial performance, but also reflected this commitment through ITC's conscious increase in the transformation of the country's social capital. It contributes to the country's economic, environmental and social capital in ITC's "triple bottom line" approach. Assuming a bigger social goal has always been the hallmark of ITC. The company believes there is no conflict between the dual goals of shareholder value enhancement and social value creation. The challenge is to develop a corporate strategy to achieve these goals in a mutually reinforcing and collaborative manner.
As a corporate citizen with a lasting relationship in rural India, ITC works with communities and government agencies to improve agricultural productivity and rural resource base. ITC's commitment to agricultural $\mathrm{R} \& \mathrm{D}$ and knowledge sharing covers important aspects of competitiveness effective agricultural practices, soil and water management.

ITC is committed to the national agenda of increasing agricultural productivity and making rural economies more socially inclusive. ITC believes that the urgency and scale of these tasks make market-related solutions and innovations more effective and sustainable than capital-intensive methods

\section{LITERATURE OF REVIEW}

Srirupa Ray (2016) analyzed the new corporate social responsibility compliance of China's largest public corporations (CPSEs) according to the 2013 Company Law, and the guidelines for corporate social responsibility and sustainability provided by the DPE (Public Enterprise) for CPSEs. It was revised by the Ministry of Heavy Industry on April 1, 2014.

Grigoris Giannarakis, George Konteos, Eleni Zafeiriou, and Xanthi Partalidou (2016) investigated whether CSR affects the financial performance of U.S. (US) companies.

Investigating the impact of corporate social responsibility on financial performance is based on participation in social responsibility initiatives rather than results. The results show that participation in social responsibility initiatives has a significant positive impact on financial performance.

Priyanka Verma \& Anupam Singh (2016) tried to bridge the gap by exploring the company's top management on how to report on corporate social responsibility. The results show that there is no significant relationship between the company's profitability and corporate social information disclosure (CSD). The conclusions reached by the study are of strong managerial significance: sincere and honest social reports can use better relationships with all stakeholders.

Miklesh Prasad Yadav and Dr. Manju Gupta (2015) studied the links between CSR initiatives taken by Indian companies and their impact on RONW. The study described the evidence that these companies 
have a negligible relationship between corporate social responsibility and net asset income (RONW).

Dr. Shailesh Ransariya (2015) studied the relationship between corporate social responsibility and the financial performance of RIL Limited. The results show that there is a positive correlation between RIL Limited's corporate social responsibility index and financial performance. However, it was not significant during the study.

Afaf Albahlol Milod Alghodban and Nathasa Mazna Ramli (2015) investigated the CSR of 61 Libyan companies in the annual reports of industry, service, investment, banking, insurance and petroleum industries. The survey results show that although many companies disclose their corporate social responsibility activities in their annual reports, the level of disclosure is still low.

B. Ramesh and Savia Mendes (2015) provided an overview of the new corporate social responsibility provisions envisaged in Article 135, and further investigated the consumption patterns that Indian companies have contributed to corporate social responsibility activities. The survey results show that in most cases, companies will not even use $1 \%$ of PAT for corporate social responsibility. By company law, this means that the corporate social responsibility budget will more than double.

Nitin Kumar (2014) tries to analyze the status of corporate social responsibility in India. Found that companies have begun to realize the importance of CSR and began to take measures.

However, due to the large scale, it is difficult for a single entity to provide information about changes. The effective partnership between enterprises, nongovernmental organizations and the government will enable India's social development to embark on a faster track.

Zafar \& Farooq (2014) studied how SMEs can improve their financial performance through proper participation in CSR practices. Corporate social responsibility can help small and medium-sized enterprises realize their reputation, trust, encouragement, attract more employees, reduce costs and increase revenue and many other organizational interests. However, most SMEs do not understand the concept of corporate social responsibility, especially in Pakistan. He suggested that SMEs must participate in CSR practices to improve society and themselves.
Premlata and Anshika Agarwal (2013) analyzed several aspects of the new CSR law in the context of modern corporate philosophy, and also drew the attention of government authorities to the practical difficulties of implementing the new regulations.

Chen Hongming and Xiao Xiaoqin (2012) discuss the applicability of factor analysis in corporate social responsibility assessment. This paper illustrates the rationality of the application of SPSS factor analysis in thermal power enterprise social responsibility assessment through SPSS factor analysis application examples.

Sanjay Pradhan, Akhilesh Ranjan (2010) tried to explore CSR practices, especially in the context of rural development. The practice of CSR for selected private and listed companies shows that corporate social responsibility actions gave a positive impact on rural communities and other business development.

Supriti Mishra, Damodar S. (2010) empirically examined the impact of corporate social responsibility on the financial and non-financial performance of Indian companies and concluded that compared with non-listed companies, listed companies show responsible business practices and Better financial performance. The results of the survey show that the business conducts of the major stakeholders may be beneficial to Indian companies in controlling the mixed effects of stock listing, ownership, and the size of the company. Managers' views on corporate social responsibility are considered to be related to corporate financial performance. This is related to the increase in non-financial performance.

Theofanis Karagiorgos (2010) explores the relationship between corporate social responsibility and corporate financial performance in Greek companies. The survey results show that there is a positive correlation between Greek company's stock returns and corporate social responsibility performance.

Christoph Lattemann, Marc Fetscherin, Ilan Alon, Shaomin Li, and Anna-Maria Schneider (2009) studied in their research why Chinese companies are associated with corporate India despite their higher level of economic growth. They experienced factors related to the country, industry, and companies in order to understand the strength of corporate social responsibility communications and concluded that Indian companies more often communicate corporate 
social responsibility through rules-based rather than relationship-based governance environments

Kenneth e. Aupperle, archie b. Carol and John D. Hatfiel (1985) used well-developed mandatory selection tools for corporate CEOs and found no relationship between social responsibility and profitability. Specifically, different levels of social orientation have not been found to correlate with performance differences.

Harpreet Singh Bedi studied the relation between social and financial performance of a company. The analysis shows that it is a positive relationship between corporate social responsibility and financial performance. Descriptive and inferential measures show that corporate social spending depends on the company's financial performance.

Mustaruddin Saleha, Norhayah Zulkiflib and Rusnah Muhamad relate the issue of whether Corporate Social Responsibility is attached to the financial performance of PLC in Malaysia. It was seen to be positively correlated to financial performance. This study shows that if local companies engage in social activities, they can achieve high-level financial performance. The results of confirmed that there is limited evidence that CSR has a significant impact on the financial performance of long-term relationships.

\section{RESEARCH METHODOLOGY}

\section{DATA ANALYSIS}

\begin{tabular}{|l|l|l|l|l|l|}
\hline Name & Year & EPS & $\begin{array}{l}\text { CSR } \\
\text { Spending } \\
\text { (in Crores) }\end{array}$ & $\begin{array}{l}\text { PBT } \\
\text { (in crores) }\end{array}$ & \multicolumn{1}{|l|}{ RONW(\%) } \\
\hline \multirow{5}{*}{ Tata Steel Ltd. } & Mar-13 & 50.28 & 170.76 & 7836.6 & 9.17 \\
\cline { 2 - 6 } & Mar-14 & 64.21 & 212 & 9713.5 & 10.49 \\
\cline { 2 - 6 } & Mar-15 & 64.49 & 171.46 & 8508.89 & 9.66 \\
\cline { 2 - 6 } & Mar-16 & 48.67 & 204 & 6126.52 & 6.95 \\
\cline { 2 - 6 } & Mar-17 & 33.67 & 193.61 & 5356.93 & 6.94 \\
\hline \multirow{4}{*}{\begin{tabular}{l} 
Lahindra \& Mahindra \\
\cline { 2 - 6 }
\end{tabular}} & Mar-13 & 54.61 & 33.53 & 4447.09 & 22.87 \\
\cline { 2 - 6 } & Mar-14 & 61.02 & 121.14 & 4369.43 & 22.8 \\
\cline { 2 - 6 } & Mar-15 & 53.47 & 236.41 & 4168.89 & 17.25 \\
\cline { 2 - 6 } & Mar-16 & 51 & 185.11 & 4229.9 & 14.59 \\
\hline
\end{tabular}

- Study the relationship between CSR and RONW.

- Determine the importance of corporate social responsibility and financial performance.

- Understand the dependence of corporate social responsibility spending on profitability.

\section{HYPOTHESIS}

H1: There is a positive correlation between CSR and Earnings per share.

H1: Corporate social responsibility is positively correlated with pre-tax profits.

H3: Companies with higher corporate social responsibility spending behavior will show higher net return.

\section{RESEARCH DESIGN}

The study is based on second-hand data collected by Tata Steel, RIL, Mahindra \& Mahindra, ITC Ltd, and websites such as Larsen and Toubro from 2013 to 2017. Various financial parameters such as earnings per share and return on equity, this study uses CSR expenditures and pre-tax profits to measure corporate social responsibility.

The data on PBT/CSR expenditure/RONW is used to examine the correlation between CSR and ROWU. The researchers used descriptive statistics, analysis of variance, and regression analysis to test hypotheses using SPSS 20 software. 
International Journal of Trend in Scientific Research and Development (IJTSRD) ISSN: 2456-6470

\begin{tabular}{|c|c|c|c|c|c|}
\hline & Mar-17 & 63.69 & 85.57 & 5187.5 & 15.41 \\
\hline \multirow{5}{*}{ ITC Ltd. } & Mar-13 & 9.39 & 82.34 & 10684.18 & 33.28 \\
\hline & Mar-14 & 11.05 & 106.63 & 12659.11 & 33.45 \\
\hline & Mar-15 & 11.99 & 214.06 & 13997.52 & 31.26 \\
\hline & Mar-16 & 12.23 & 247.5 & 14958.39 & 29.9 \\
\hline & Mar-17 & 8.4 & 275.96 & 15502.96 & 22.5 \\
\hline \multirow{5}{*}{$\begin{array}{l}\text { Reliance Industries } \\
\text { Ltd. }\end{array}$} & Mar-13 & 65.05 & 351 & 26284 & 11.67 \\
\hline & Mar-14 & 68.02 & 711.72 & 27818 & 11.15 \\
\hline & Mar-15 & 70.21 & 760.58 & 29468 & 10.51 \\
\hline & Mar-16 & 84.61 & 652 & 35701 & 11.41 \\
\hline & Mar-17 & 96.65 & 674 & 40777 & 10.9 \\
\hline \multirow[t]{5}{*}{ Larsen \& Toubro Ltd. } & Mar-13 & 79.8 & 73.167 & 6711.15 & 16.85 \\
\hline & Mar-14 & 59.26 & 76.9 & 7267.91 & 16.32 \\
\hline & Mar-15 & 54.39 & 106.176 & 6757.84 & 13.63 \\
\hline & Mar-16 & 57.02 & 119.51 & 6689.11 & 13.04 \\
\hline & Mar-17 & 58.46 & 100.77 & 6757.84 & 11.85 \\
\hline
\end{tabular}

Table 4.1

\section{Descriptive Statistics}

\begin{tabular}{|c|c|c|c|c|c|c|c|}
\hline & $\mathbf{N}$ & Minimum & Maximum & Mean & $\begin{array}{l}\text { Std. } \\
\text { Deviation }\end{array}$ & Skewne & \\
\hline & Statistic & Statistic & $\begin{array}{l}\text { Statistic } \\
\text { Ste }\end{array}$ & Statistic & Statistic & Statistic & $\begin{array}{l}\text { Std. } \\
\text { Error }\end{array}$ \\
\hline EPS & 25 & 8 & $97: 2456$ & 51.60 & 24.396 & -.569 & .464 \\
\hline CSR & 25 & 34 & 761 & 246.72 & 215.195 & 1.545 & .464 \\
\hline Spending & & 28 & & 20 & 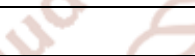 & & \\
\hline (in Crores) & & & 10000 & & $\angle$ & & \\
\hline PBT (in & 25 & 4169 & 40777 & 12879. & 10581.732 & 1.485 & .464 \\
\hline crores) & & 4 & 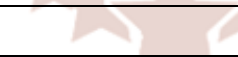 & 24 & 3 & & \\
\hline RONW(\%) & 25 & 6.94 & 33.00 & 16.528 & 8.05246 & .996 & .464 \\
\hline & & & $e_{u}$ & 4 & & & \\
\hline Valid $\mathrm{N}$ & 25 & & & & & & \\
\hline (listwise) & & & & & & & \\
\hline
\end{tabular}

\section{Table 4.2}

In the selected companies, the mean EPS is 51.60. Except ITC Ltd, all other companies achieved more than the mean score of EPS. The mean score of CSR is 246.72 crores. With respect to CSR, Reliance Industries Ltd. achieved higher score than Mean CSR score. When it comes talking about, profit before tax (PBT), and the mean score of is 12879.24 crores. ITC Ltd. and Reliance Industries Ltd. achieved greater PBT than average level of PBT. The average score of
RONW is $16.5284 \%$. ITC Ltd and Mahindra \& Mahindra achieved higher level than the mean level.

Considering all the conditions, it has been observed that Reliance Industries Ltd. achieved more score than the mean level. 
ANOVAa

\begin{tabular}{|ll|l|l|l|l|l|}
\hline Model & & $\begin{array}{l}\text { Sum } \\
\text { Squares }\end{array}$ & Df & $\begin{array}{l}\text { Mean } \\
\text { Square }\end{array}$ & F & Sig. \\
\hline 1 & Regression & 2419.315 & 1 & 2419.315 & 4.690 & $.041^{\mathrm{b}}$ \\
& Residual & 11864.685 & 23 & 515.856 & & \\
& Total & 14284.000 & 24 & & & \\
\hline
\end{tabular}

a. Dependent Variable: EPS

b. Predictors: (Constant), CSR Spending (in Crores)

Table 4.3

To test the H1, Table3 has been taken care. The between CSR and Earning per share) is accepted. It regression of EPS on CSR score output yields an Adjusted R Square $=-0.412, \mathrm{R}$ Square $=0.169, \mathrm{R}$ $=0.096, \mathrm{~F}=4.690, \mathrm{P}=0.41$ and $\mathrm{Df}=24$. The pvalue for each term tests the null hypothesis that the coefficient is equal to zero (no effect). A low p-value $(<0.05)$ indicates that you can reject the null hypothesis. So in table $3 \mathrm{p}$ is 0.041 which is less than .05 so there is a significant between the CSR spending means that when firms increase CSR spending, their EPS also increases. It is also indicating that corporate social responsibility is an important tool in achieving effective financial performance in these five companies (Tata Steel Company, ITC, Mahindra \& Mahindra, Reliance Industries and Larsen and Toubro Ltd.). It shows that $\mathrm{R}$ Square is 0.169 which accounted for about $16.9 \%$ variation in the EPS. and EPS. Hence H1 (There is positive relationship

Model Summary

\begin{tabular}{|c|c|c|c|c|c|c|c|c|c|}
\hline \multirow[t]{2}{*}{ Mode 1} & \multirow[t]{2}{*}{$\mathrm{R}$} & \multirow{2}{*}{$\begin{array}{l}\mathrm{R} \\
\text { Square }\end{array}$} & \multirow{2}{*}{$\begin{array}{l}\text { Adjusted } \\
\text { R Square }\end{array}$} & \multirow{2}{*}{$\begin{array}{l}\text { Std. Orror } \\
\text { of the } \\
\text { Estimate } \\
\text { Develop }\end{array}$} & \multicolumn{5}{|c|}{ Change Statistics } \\
\hline & & & & & $\begin{array}{l}\text { R } \\
\text { Square } \\
\text { Change }\end{array}$ & $\begin{array}{l}\mathrm{F} \\
\text { Change }\end{array}$ & df1 & $\mathrm{df} 2$ & $\begin{array}{l}\text { Sig. F } \\
\text { Change }\end{array}$ \\
\hline 1 & $.902^{\mathrm{a}}$ & .813 & .805 & $\begin{array}{l}4672.85 \\
4\end{array}$ & .813 & 100.072 & 1 & 23 & .000 \\
\hline
\end{tabular}

a. Predictors: (Constant), CSR Spending (in Crores)

\section{ANOVA}

\begin{tabular}{|ll|l|l|l|l|l|}
\hline \multicolumn{2}{|l|}{ Model } & Sum of Squares & Df & Mean Square & F & Sig. \\
\hline 1 & Regression & 2185135288.45 & 1 & 2185135288.459 & 100.072 & $.000 \mathrm{~b}$ \\
& 9 & & & & \\
Residual & 502217978.101 & 23 & 21835564.265 & & \\
Total & 2687353266.56 & 24 & & & \\
& 0 & & & & \\
& & & & & & \\
& & &
\end{tabular}

a. Dependent Variable: PBT (in crores)

b. Predictors: (Constant), CSR Spending (in Crores)

\section{Table 4.4}

To test the $\mathrm{H} 2$, Table 4 has been taken care. The regression of PBT on CSR score output yields an Adjusted $\mathrm{R}=0.902$, R Square $=0.819$, Adjusted R Square $=0.805, F=100.072, \mathrm{P}=0.000$ and $\mathrm{Df}=24$. The p-value for each term tests the null hypothesis that the coefficient is equal to zero (no effect). A low p-value $(<0.05)$ indicates that you can reject the null hypothesis. So in table $3 \mathrm{p}$ is 0.000 which is less than .05 so there is a significant between the CSR spending and EPS. Hence H1 (There is positive relationship 
between CSR and Profit before Tax) is accepted. It means that when firms increase CSR spending, their PBT also increases. It is also indicating that corporate social responsibility is an important tool in achieving effective financial performance in these five companies (Tata Steel Company, ITC, Mahindra \& Mahindra, Reliance Industries and Larsen and Toubro Ltd.). It shows that $\mathrm{R}$ Square is 0.813 which accounted for about $81.3 \%$ variation in the PBT.

\section{CORRELATIONS}

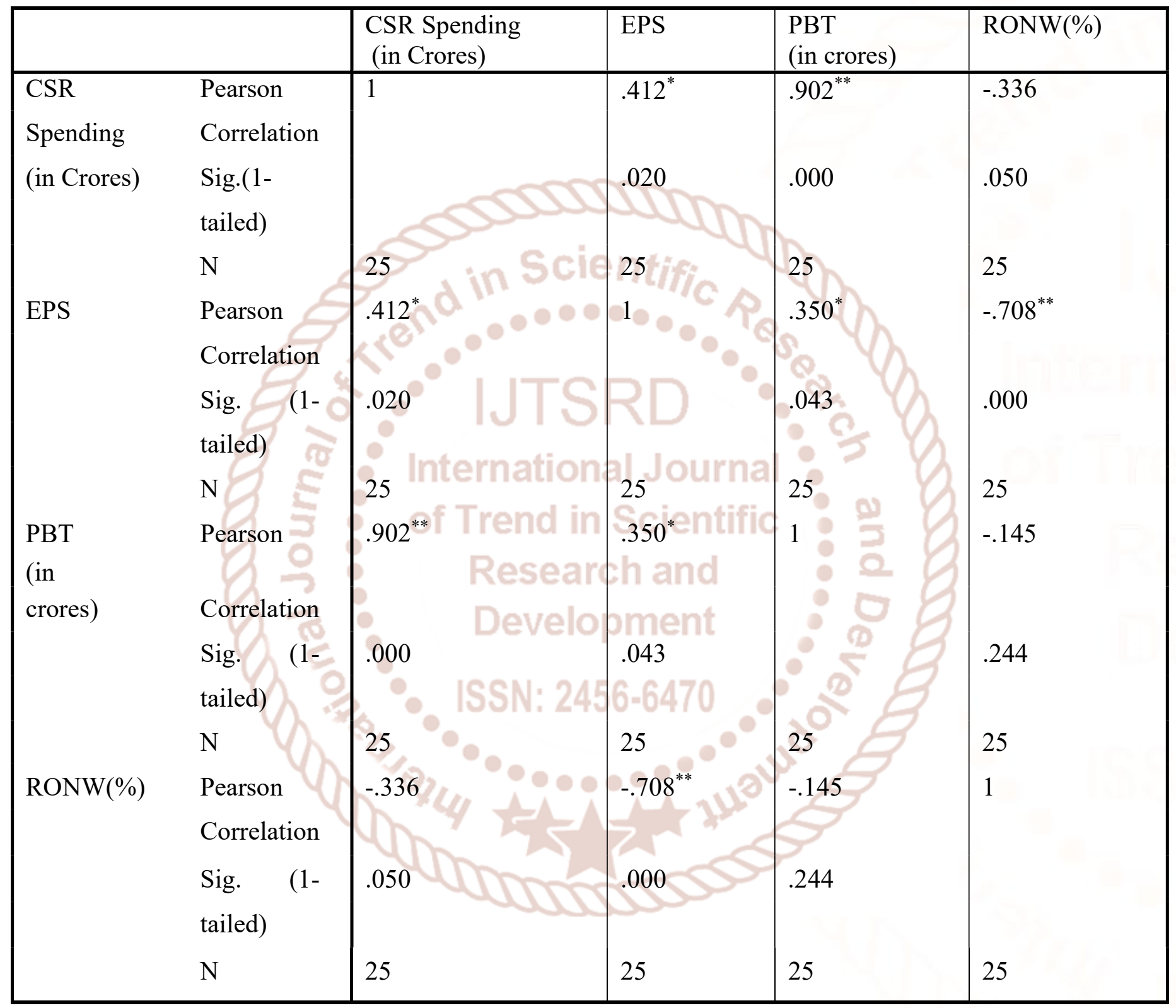

*. Correlation is significant at the 0.05 level (1-tailed).

**. Correlation is significant at the 0.01 level (1-tailed). 


\section{Model Summary}

\begin{tabular}{|c|c|c|c|c|c|c|c|c|c|}
\hline \multirow[b]{2}{*}{ Model } & \multirow[b]{2}{*}{$\mathrm{R}$} & \multirow[b]{2}{*}{$\begin{array}{l}\mathrm{R} \\
\text { Square }\end{array}$} & \multirow[b]{2}{*}{$\begin{array}{l}\text { Adjusted } \\
\text { Square }\end{array}$} & \multirow{2}{*}{$\begin{array}{l}\mathrm{R} \text { Std. Error of the } \\
\text { Estimate }\end{array}$} & \multicolumn{5}{|c|}{ Change Statistics } \\
\hline & & & & & $\begin{array}{l}\mathrm{R} \\
\text { Square } \\
\text { Change }\end{array}$ & $\begin{array}{l}\text { F } \\
\text { Change }\end{array}$ & df1 & df2 & $\begin{array}{l}\text { Sig. F } \\
\text { Change }\end{array}$ \\
\hline 1 & $.336 a$ & .113 & .075 & 7.74669 & .113 & 2.932 & 1 & 23 & 100 \\
\hline
\end{tabular}

a. Predictors: (Constant), CSR Spending (in Crores)

\section{ANOVAa}

\begin{tabular}{|c|c|c|c|c|c|c|}
\hline & & $\begin{array}{l}\text { Sum of } \\
\text { Squares }\end{array}$ & Df & $\begin{array}{l}\text { Mean } \\
\text { Square }\end{array}$ & $\mathrm{F}$ & Sig. \\
\hline 1 & $\begin{array}{l}\text { Regression } \\
\text { Residual } \\
\text { Total }\end{array}$ & $\begin{array}{l}175.954 \\
1380.256 \\
1556.211\end{array}$ & $\begin{array}{l}1 \\
23 \\
b 4\end{array}$ & $\begin{array}{l}175.954 \\
60.011\end{array}$ & 2.932 & $100 \mathrm{~b}$ \\
\hline
\end{tabular}

a. Dependent Variable: RONW(\%)

b. Predictors: (Constant), CSR Spending (in Crores)

\section{Table 4.6}

To test the H3, Table5 has been taken care. The regression of RONW on CSR score output yields an $\mathrm{R}$ $=0.336, \mathrm{R}$ Square $=0.113$, Adjusted R Square $=0.075$, $\mathrm{F}=2.932, \mathrm{P}=0.100$ and $\mathrm{Df}=24$. The $\mathrm{p}$-value for every term tests the null hypothesis and that the coefficient is equal to zero ( 0$)$ (no effect). A low pvalue $(<0.05)$ indicates that you can reject the null hypothesis. So in table $3 p$ is 0.100 that which is more than .05 so there is an insignificant between the CSR spending and RONW. Hence H2 (Firms with higher CSR spending action will exhibit higher return on net worth) is rejected. It means spending societal activities does not lead to increase return on net worth irrespective of Tata Steel Company, RIL, Mahindra \& Mahindra, Infosys and Larsen and Toubro Ltd.

\section{CONCLUSION}

Based on the analysis and interpretation of the design studies in this study, to answer whether corporate social responsibility expenditures affect the above companies' RONW. The study concluded that there is a negligible relationship between corporate social responsibility and corporate social responsibility, because there is a positive relationship between corporate social responsibility and corporate social responsibility. This means that corporate social responsibility expenditure has little impact on the company's EPS and PBT, and it has a great influence on RONW. Increased corporate social responsibility expenditures lead to an increase in EPS.
Corporate social responsibility helps innovation to satisfy consumers, seize market opportunities and differentiate them from others so that they can be more competent in selected companies. The following arguments address some of the limitations of the study and how to overcome them. The first limitation is that the results obtained using various financial parameters are inconsistent. This problem can be measured through the future research more concerned with the choice of corporate financial parameters to measure the profitability of corporate social responsibility research. Second, the sample size in this study comes from five Indian companies that do not reflect the entire public sector. Finally, as the study only considers a five-year assessment, these findings should be interpreted with caution. Future research in this area must consider the need to extend the number of research phases to assess recent legal requirements.

\section{REFERENCES}

1. Christoph Lattemann, Marc Fetscherin, Ilan Alon, Shaomin Li, and Anna-Maria Schneider,2009, CSR Communication Intensity in Chinese and Indian Multinational Companies, Corporate Governance: An International Review, 2009, 17(4): 426-442

2. Pradhan S., Ranjan A, 2010, -Corporate Social Responsibility in Rural Development Sector: 
Evidences from India, School of Doctoral Studies (European Union) Journal - 2010

3. Supriti Mishra and Damodar Suar, Does Corporate Social Responsibility Influence Firm Performance of Indian Companies?, Journal of Business Ethics (2010) 95:571-601

4. Afaf Albahlol Milod Alghodban and Nathasa Mazna Ramli,2015, corporate social responsibility disclosure in libyan companies, International Journal of Business, Economics and Law, Vol. 8, Issue 1 (Dec.) ISSN 2289-1552

5. B. Ramesh \& Savia mendes (2015), corporate social responsibility - perspectives in Indian context, Australian journal of business and economic studies Volume 1 no. 2,pp 93-101

6. Srirupa Ray (2017), Corporate Social Responsibility: An Analysis on Central Public Sector Undertakings in Indian Context, IMS Business School Presents Doctoral Colloquium 2017, pp49-55

7. Premlata \& Anshika Agarwal (2013), Corporate Social Responsibility: An Indian Perspective, Journal of Business Law and Ethics, Vol. 1 No. 1, December 2013

8. Dr.Fareeha.Zafar \& Mudassar Farooq, Corporate Social Responsibility in Small and Medium Enterprises to Achieve Organizational Benefits, International Journal of Scientific \& Engineering Research, Volume 5, Issue 1, January-2014 ISSN 2229-5518

9. Nitin Kumar, corporate social responsibility: an analysis of impact and challenges in india, Abhinav International Monthly Refereed Journal of Research in Management \& Technology, Volume 3, Issue 5 (May, 2014) Online ISSN2320-0073, pp 97-104
10. Priyanka Verma \& Anupam Singh, Fostering Stakeholders Trust through CSR Reporting: An Analytical Focus, IIM Kozhikode Society \& Management Review,5(2) 186-199@ 2016 Indian Instituteof Management Kozhikode

11. Kenneth E. Aupperle, Archie B. Carroll and John D. Hatfield, An Empirical Exmination of the relationship between corporate social responsibility and profitability, The Academy of Management Journal, Vol. 28, No. 2 (Jun., 1985), pp. 446-463Published by: Academy of Management

12. Hongming Chen \& Xiaocan Xiao, The Application of SPSS Factor Analysis in the Evaluation of Corporate Social Responsibility, JOURNAL OF SOFTWARE, VOL. 7, NO. 6, JUNE 2012, pp 1258-1264

13. Harpreet singh bedi, financial performance and social responsibility:indian scenario Mustaruddin Saleh,Norhayah Zulkifli,Rusnah Muhamad, An Empirical Examination of the Relationship between Corporate Social Responsibility Disclosure and Financial Performance in an Emerging Market

14. Theofanis Karagiorgos, Corporate Social Responsibility and Financial Performance: An Empirical Analysis on Greek Companies, European Research Studies, Volume XIII, Issue (4), 2010

15. Grigoris Giannarakis,George Konteos,Eleni Zafeiriou\&Xanthi Partalidou, The impact of corporate social responsibility on financial performance, Investment Management and Financial Innovations, Volume 13, Issue 3, 2016

16. Adriana Galant \& Simon Cadez, Corporate social responsibility and financial performance relationship: a review of measurement approaches, Economic Research- Ekonomska Istraživanja, 2017 VO L. 30, NO. 1, 676-693 